\title{
GENTIANA CHAZAROI (GENTIANACEAE), A NEW WESTERN MEXICAN SPECIES
}

\author{
HUGH H. ILTIS \\ Department of Botany \\ 430 Lincoln Dr., Birge Hall \\ University of Wisconsin-Madison \\ Madison, Wisconsin, U.S.A. 53706-1381
}

\section{RESUMEN}

Se describe una nueva especie de Gentiana, sección Pneumonanthe, relacionada a G. ovatiloba Kusn. Se trata de una hierba pequeña, tal vez rizomatoza, de hojas pequeñas y flores pequeñas azules, que crece en las cercanías de La Ciudad, Durango, en las estribaciones de La Sierra Madre Occidental, México.

\begin{abstract}
A new, small-leaved, blue-flowered, slenderly rhizomatous Gentiana of section Pneumonanthe related to the larger-flowered G. ovatiloba Kusn. is described from La Ciudad, on the crest of the Sierra Madre Occidental, Durango, Mexico.
\end{abstract}

Gentiana (Sect. Pneumonanthe) chazaroi Iltis, sp. nov. (Figs. 1-2).

Herba perennis; glabra, gracilis, simplex. Caules 1-5, procumbentes vel ascendentes, 5-13 cm longi, $1 \mathrm{~mm}$ lati. Folia aliquanto succulenta, 5-23 mm longa, 3-7 $\mathrm{mm}$ lata, obovata-spatulata vel rotundata-spatulata, in 10-18 paribus decussatis. Flores 1-4, terminales, \pm subsessiles. Tubus calycis $3-5 \mathrm{~mm}$ longus; lobi calyci lineari-oblanceolati, acuti, 3-7 mm longi. Tubus corollae urceolato-cylindricus, 7-12 mm longus, 4-6 mm latus; lobi corollae elliptico-obovati, $5.6-6.3 \mathrm{~mm}$ longi, $3.5-4 \mathrm{~mm}$ lati, integri, \pm obtusi, lazulini; plicae inter lobis sitae (appendices) 2/3 loborum longitudinem aequantes, \pm rotundatae, apiculatae, interdum incisae.

Delicate, small perennials from slender horizontal rhizomes (4 mm diam.; cf. Fig. 2, C), ca. $1 \mathrm{~cm}$ beneath the soil surface (and probably also from an erect caudex or tap root?). Stems ascending to prostrate, $5-13 \mathrm{~cm}$ long, very thin (1 $\mathrm{mm}$ diam.) and flexible, solitary or 2-3 from one base.

Leaves somewhat fleshy, the midrib obscure or lacking above, raised beneath, elliptic-obovate or spatulate to orbicular, rounded to obtuse at apex, gradually attenuate to abruptly contracted and almost sessile, (5-)9-13 mm long, 3-7 mm wide, \pm closely spaced, in 10-18 decussate pairs, the lower reduced and usually more widely spaced, the near the base of the stem reduced to minute, basally connate scales; petioles short, v-shaped (in 


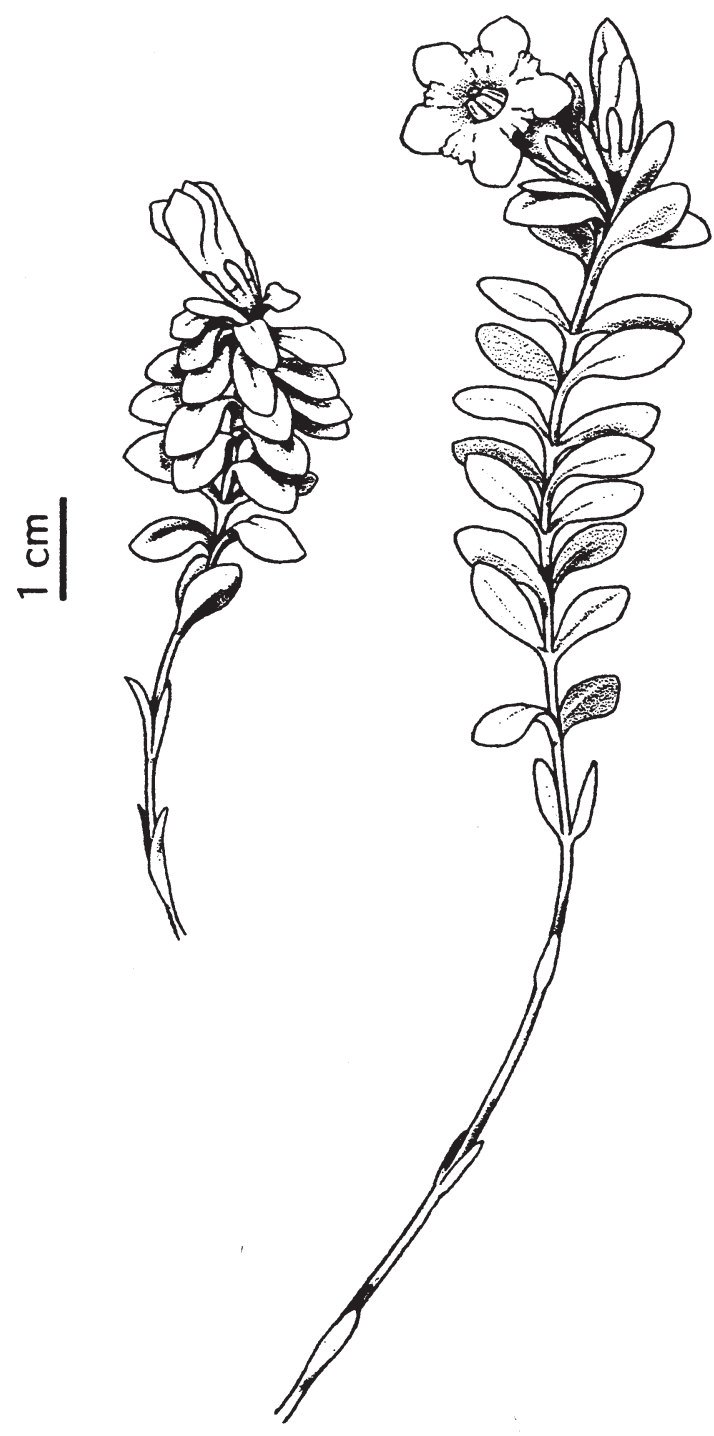

Fig. 1. Gentiana chazaroi, habit sketch of two stems. Except for the rhizome shown in Fig. $2 \mathrm{C}$, the subterranean parts of this species are unknown. 
Iltis: Gentiana chazaroi, a New Western Mexican Species

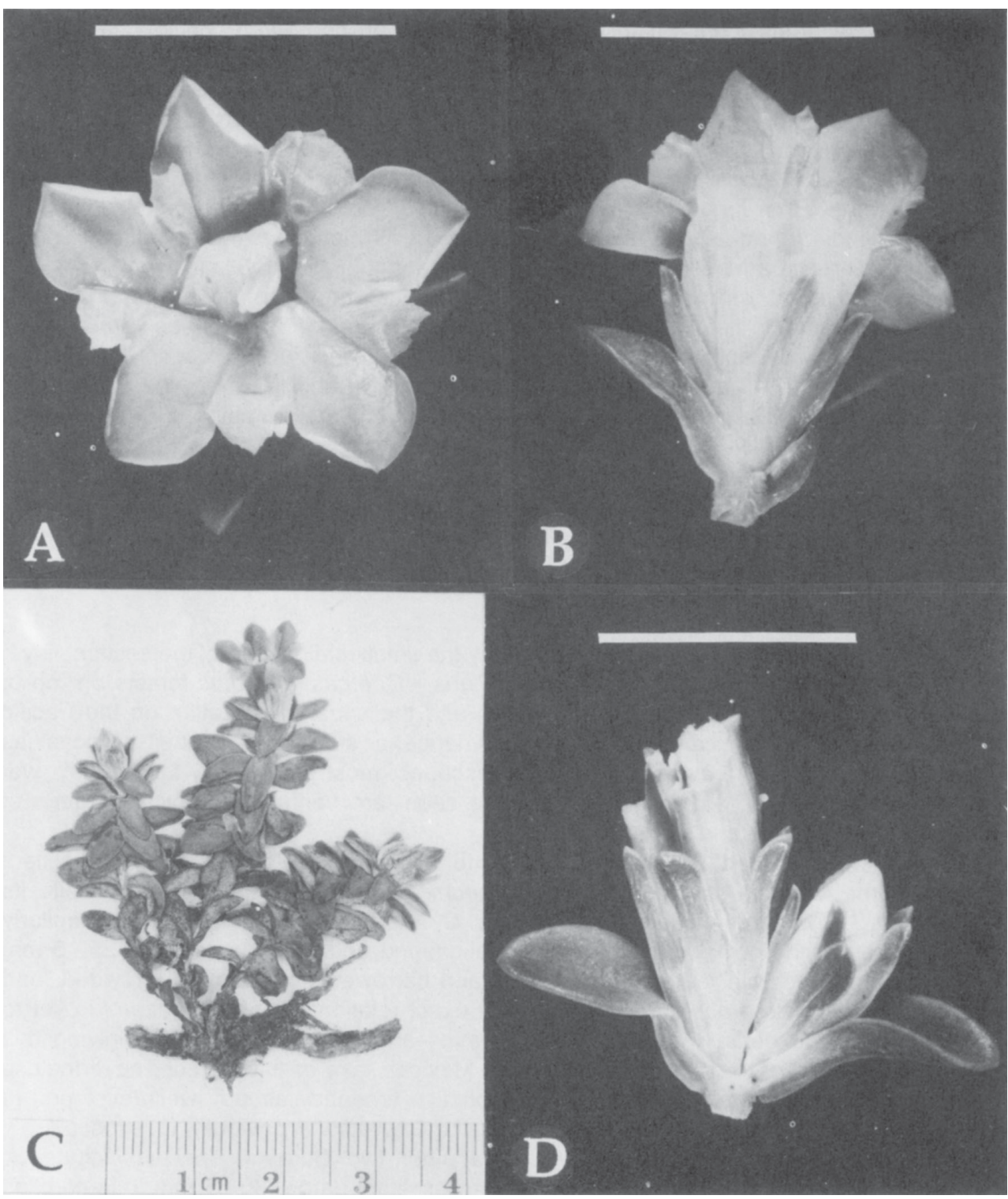

Fig. 2. Gentiana chazaroi. A, B, D. (Scale $=1 \mathrm{~cm})$. Front and back views of flower remoistened from dried material to show corolla, calyx, and in $D$, paired bracts and uppermost leaves. The apex of the terminal bud in D was removed. C. Small plant with three stems originating from a horizontal rhizome and terminating in 1-2 flowers. 
cross-section), decurrent onto the stem and connate at their very base; leaf margins smoothly entire, translucent-crustose, slightly revolute (in herbarium specimens).

Flower buds (tube plus lobes) 10-18 mm long, narrowly oblong, pointed, closely subtended by a pair of sepal-like, linear-oblanceolate, 6-9 $\mathrm{mm}$ long bracts, these in turn by a pair of small leaves; flowers 1-4, terminal in a corymbose cluster or solitary (Fig. $2, \mathrm{C})$, subsessile or in pairs on a very short $(5-7 \mathrm{~mm})$ peduncle-like branchlet. Calyx tube 3-5 mm long; calyx lobes erect and arching outward, narrowly oblong to linear-elliptic or oblanceolate, 4-7 mm long, 0.6-1.5 mm wide, acute. Corolla blue, not spotted, the tube urceolate-cylindric, gradually expanding upward, 7-12 mm long, ca. 4-6 mm diam.; corolla lobes spreading, broadly elliptic-obovate to ovate-triangular, $5.6-6.3 \mathrm{~mm}$ long, $3.5-4 \mathrm{~mm}$ wide, entire, rounded to broadly acute, the sinuses equal, the open (dry) flower 11-14 mm across from petal tip to petal tip; interpetal folds (appendages) $2 / 3$ as long as corolla lobes, \pm rounded (not bifid), apiculate and occasionally with an incision or two on one or both sides. Anthers free, 4-5 mm long; filaments $8-10 \mathrm{~mm}$ long and free from the corolla tube for 4-5 mm. Pistil 9-12 $\mathrm{mm}$ long, the very short styles divergent-arching. Fruit and seeds unknown.

TYPE: Mexico: Durango, cerca de La Ciudad, Mpio. Pueblo Nuevo, Carretera Durango - Mazatlán: Hierba postrada, flores azules, abundante, en bosque de Pinus Quercus - Arbutus, 10 Marzo 1991 (fl.), M. Cházaro B., P. D. Sorensen \& S. González 6562 (HOLOTYPE: WIS!; ISOTYPES: IEB, MEXU).

This remarkably distinct species, probably the smallest-flowered of the section, is yet another endemic from the often burned-over Pinus - Quercus - Arbutus forests on top of the Sierra Madre Occidental between Durango and the coast at Mazatlan on the Pacific Coast, at elevations of ca. $2000 \mathrm{~m}$, from whence a surprising number of novelties (Fimbristylis, Stipa, etc.) have recently been described, most presumably from sunny, wet seepage slopes, which, as I have myself once seen, are veritable botanical gardens of herbaceous perennials and annuals.

The only Mexican relative that comes to mind, using Pringle's (1977) excellent revision of the Mexican species of section Pneumonanthe Gaudin, to which, despite its small size, G. chazaroi evidently belongs, is G. ovatiloba Kusn., a species similarly decumbent but with flowers more openly funnel-shaped and much larger (i.e., 25-45 mm vs. 10-18 mm), and with leaves much longer and narrower, not nearly as crowded, and borne on stiffer, more erect stems. Though the exact relationship of $G$. chazaroi is yet to be determined, the densely crowded, small leaves and short slender stems; giving this species an "alpine" aspect lacking in the other Mexican taxa of this section, nevertheless suggest an extreme development of a size reduction tendency already well-developed in the allopatric southeastern Mexican and Guatemalan G. ovatiloba, obviously the most closely related, and probably ancestral, species. The other two Durango species include $G$. bicuspidata (G. Don.) Briq., with linear leaves and solitary, large, 30-35 mm long corollas and long slender calyx lobes, and G. hooperi Pringle, which, though similar in overall size to G. chazaroi, has narrowly elliptic leaves, solitary short-pedicellate, large (35-55 $\mathrm{mm}$ long), funnel-shaped flowers, with the very short $(2-5 \mathrm{~mm})$, slenderly triangular calyx lobes borne on a long $(8-16 \mathrm{~mm})$ calyx tube. 
It gives me great pleasure to dedicate this species to its discoverer, Ing. Miguel Cházaro Basáñez (born 1949), my student at the University of Wisconsin in the 1980's, now botanist at the Instituto de Geografia y Estadistica, Universidad de Guadalajara, Jalisco, an expert on Mexican Loranthaceae, Agavaceae, and the flora of Veracruz, but above all a tireless collector of his beloved Mexican flora.

\section{ACKNOWLEDGEMENTS}

Thanks are due M. Wetter for manuscript suggestions, Antonio Vázquez for the Spanish abstract, and Claudia Lipke and Kandis Elliot for the illustrations. Generously supported by the Ethel K. and Oscar N. Allen Fund of the University of Wisconsin-Madison Herbarium, this study is therefore, gratefully dedicated to Ethel K. Allen, our herbarium's very own "madrina" ["godmother"], on the occasion of her 87th birthday.

\section{LITERATURE CITED}

Pringle, J. S. 1977. Taxomony and distribution of Gentiana (Gentianaceae) in Mexico and Central America. I. Sect. Pneumonanthe. Sida 7: 174-217. 